class of the 4th V.B. Lirerpool Regiment instructed by Surgeons Wills and Fleetwood, and since then the work has extended throughout the whole police force in Lancashire. Dr. Wills conceived the idea of utilizing the fire brigade men and horses of the Bootle Corporation in connexion with a horse ambulance instead of the "Ashford" litters then in use at the docks. After repeated applications to the Bootle Counsil he succeeded in carrying out his project by securing the services of the men and horses, with the result that since 1889 a horse ambulance (generously presented by the late W. A. Matheson) has rendered valuable service in thousands of urgent cases at little extra cost to the borough. We believe that this was the fil'st horse ambulance to be worked by the police or fire brigades in Lancashire.

Dr. Wills was a Mason, and in politics a strong Conservative; he served on the town council for six years, and was Vice-President of the Conservative Association of the Bootle Division of Lancashire for some years. In 1888 he was appointed a Justice of the Peace for the Borough of Bootle. He was for some time a Vice-President of the Lancashire and Cheshire Branch of the British Medical Association. Some years ago he retired from practice owing to failing health. He married, in 1877, Elizabeth Hannah, daughter of the late Surgeon-Major Joseph T. Glover, M.D. (Indian Army), who survives him. He leaves three sons and two daughters; his eldest son is a graduate in medicine of Cambridge University.

THE LATE SIR W. ALLCHIN.

Mr. A. Campbell Stark, M.B., B.S.Lond., writes : In your obituary notice of the late Sir William Allchin, I think inadequate justice was done to his merit as a clinical teacher. The school with which he was associated was a small one, and only those who were privileged to work under him could realize how great were his powers in that direction. His method was to take a case selected for him by his house-physician, and of the nature of which he was entirely ignorant, and to ask a student to investigate it. Then by cross-questioning on the observations made the listeners were led to form a vivid mental picture of the patient's condition, and from that to a diagnosis. The method was peculiar but most effective and instructive, and Sir William was very seldom wrong, although I think he cared little for the name of the disease, but much that we should realize the pathological condition we had to deal with. In these days, when the mass of recorded facts has become so enormous, a teacher who will inculcate principles confers a great boon on his students, and this was Sir William Allchin's peculiar merit.

\section{Atediral flatur.}

Sir GEorge Beatson, K.C.B , M.D., will deliver a lecture on Treatment of Acute Appendicitis: When and How to Operate, at the Polyclinic, Chenies Street, W.C., on Tuesday, February 27 th, at 5.15 p.m. The lecture will be open to all members of the profession.

AN interesting discussion on The Inheritance of Some Human Abnormalities was opened by Dr. Alfred M. Gossage at the February afternoon meeting of the Eugenics Education Society; which was held at the Grafton Galleries on Thursday, February 15th. There are certain abnormalities, said Dr. Gossage, which it would be extremely difficult, if not impossible, to obliterate entirely from the human race, since their abolition involves a ruthless prohibition of marriage for every member of a tainted family, whether normal or otherwise. For instance, both haemophilia and keratosis might be transmuted to their offspring by the normal children of affected persons; and these conditions, therefore, could never be eliminated so long as any member of the family is allowed to propagate. On the other hand, to forbid the marriage of norma people was by no means easy, nor was it always advisable; for in the case of keratosis, for example, the disease does not seriously interfere with the well-being of the patient, and therefore did not justify such high-handed methods of extermination. What was really needed for the well-being of the race was legislation which would control the present wholesale propagation of insanity, idiocy, and disease by the reckless intermarriage of degenerates, and the encouragement of marriage amongst the fit, who at the present moment were just those members of the community who could least afford to have children

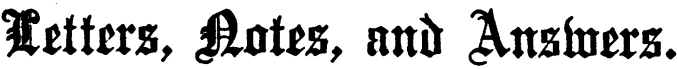

ORIGINAL ARTICLES and LETTERS forwa: ded for publication are understood to be offered to the BRITISH MEDICAL JOURNAL alone unles the contrary be stated.

DTHOns desiring reprints of their articles published in the BrITIsA MEDICAL JOURNAI are requested to communicate with the Office. 429, Strand, W.C.. on receipt of proof.

MANUSCRIPTS FORWARDED TO THE OFFICE OF THIS JodRNal CANNOT UNDER ANY CIRCUMSTANCES BE RETURNED.

tions should necessarily for publication.

CoRRESPONDENTs not answered are requested to look at the Notices to Correspondents of the following week.

CoMmonICATIONS respecting Editorial matters should be addressed to the Editor. 429, Strand, London, W.C.; those concerning busincs matters, advertisements, non-delivery of the JoURNAI, etc., should be addressed to the Office, 429 , Strand, London. W.C.

FLEGRAPHIC ADDress.-The telegraphic address of the EDITOR of The telegraphio address of the BRITISH MEDICAL JOURNAL is Articulate. London.

TELEP 2631, Gerrari, FDITOR. BRITISH MEDICAL JOURNAL. 2630. Gerrard, BRITISH MEDICAL ASSOCIATION. 2634. Gerrard, MEDICAL SECRETARY.

ST Queries, answers, and communications relating to subjects to which special departments of the BRITISB MEDICAL JoURNAL are devoted will be found under their respective headings.

\section{QU⿴囗大)}

INCOME TAX.

Perplexed has sold his practice, and wishes to know how the sum received from the sale is to be dealt with in his nex income tax return; also whether the officer can demand to know the amount paid for the practice, or in what way it is invested.

** The sum received on the sale is not a matter that affects our correspondent's income in any sense, except in so far as, when invested, it may, like any other capital, produce income that will be subject to income tax. No Governrisent officer is entitled to know the amount paid for the practice, nor the manner in which it is invested.

KELOID AFTER APPENDICECTOMY.

M.V.O.M., F.R.C.S. would be very glad to hear of any hopeful treatment for \& patient who has four times needed laparotomy for keloid scar and extensive abdominal adhesions following appendicectomy. The scar grows until it splits from central necrosis from anaemia, the adhesions cause increasing dragging pain and sickness. Massage, fibrolysin, waiting to the absolute limit of endurance, bed for six weeks, have all been absolute limit of endurance, bed for six weeks, have all been was swabbed over the intestines. This delayed the adhesion was swabbed over the intestines. This delayed the adhesion keloid.

\section{ANSWERS.}

J. R. writes : “H. W.'s" patient is suffering from a neurosis of the 'phobia order to which he cannot give a special name he has no doubt that the condition would yield at once to treatment by hypnotic suggestion.

IPswich writes from the same point of view to recommend strychnine and iron, and adds that prevention of constipation is very necessary.

Mr. Bowles, SURgeon, of High Wycombe. MR. MACLEOD YEARSLEY (London) writes: It may interest of the Royal House of Stuart, held in 1891 at the New Gallery, occurs the following: "374. Glove of Charles I, worn by the King on the scaffold. Lent by V. F. Bennett-Stanford, Esq."

\section{LETTERS, NOTES, ETC.}

$$
\text { A CoRRECTION. }
$$

Is Mr. Moynihan's address on the Correlation of Symptoms and Signs in Some Abdominal Diseases, in the JouRNAL of from foot) was, we regret, printed for "Hutchinson."

BCALE OF CFERGES FOR ADYERTIBEAENTS IN TEE

Eight lines and under Fach additional line

A page

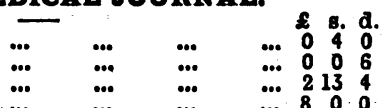$$
\text { Än average line contains six words. } \ldots 8^{\circ}
$$
All remittances by Post Ofice Orders must be made payable to No responsibility will be accepted for any such remittance not so Bafeguarded.

Advertisements should be delivered, addressed to the Manager, 429, Strand, London, not later than the first post on.Wednesdaymornine preceding publication, and, if not paid for at the time, should be Nort. - It is against the

Nork. - It is against the rules of the Post Office to recelve noste 